\title{
Unravelling the controls on the molybdenum isotope ratios of river waters
}

\author{
K. Horan ${ }^{1 *}$, R.G. Hilton ${ }^{2}$, A.J. McCoy-West ${ }^{1,3}$, D. Selby ${ }^{1,4}$, \\ E.T. Tipper ${ }^{5}$, S. Hawley ${ }^{1}$, K.W. Burton ${ }^{1}$
}

Abstract

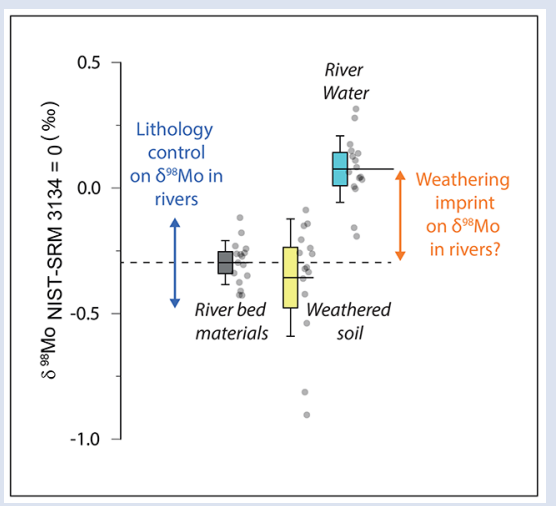

The molybdenum $(\mathrm{Mo})$ isotope ratios $\left(\delta^{98 / 95} \mathrm{Mo}\right)$ of river waters control the $\delta^{98 / 95} \mathrm{Mo}$ values of seawater and impact on the use of Mo isotope ratios as a proxy of past redox conditions. The $\delta^{98 / 95} \mathrm{Mo}$ values of river waters vary by more than $2 \%$, yet the relative roles of lithology versus fractionation during weathering remain contested. Here, we combine measurements from river waters $\left(\delta^{98 / 95} \mathrm{Mo}_{\text {diss }}\right)$, river bed materials $\left(\delta^{98 / 95} \mathrm{Mo}_{\mathrm{BM}}\right)$ and soils from locations with contrasting lithology. The $\delta^{98 / 95} \mathrm{Mo}$ values of river bed materials $\left(\delta^{98 / 95} \mathrm{Mo}_{\mathrm{BM}}\right)$, set by rock type, vary by $\sim 1 \%$ o between rivers in New Zealand, the Mackenzie Basin, and Iceland. However, the difference between dissolved and solid phase Mo isotopes $\left(\Delta^{98 / 95} \mathrm{Mo}_{\text {diss-BM }}\right)$ varies from $+0.3 \%$ to $+1.0 \%$ o. We estimate Mo removal from solution using the mobile trace element rhenium and find that it correlates with $\Delta^{98 / 95} \mathrm{Mo}_{\text {diss-BM }}$ across the sample set. The adsorption of Mo to Fe-Mn-(oxyhydr) oxides can explain the observed fractionation. Together, the amount of Mo released through dissolution and taken up by (oxyhydr)oxide formation on land may cause changes in the $\delta^{98 / 95}$ Mo values of rivers, driving long term changes in the Mo isotope ratios of seawater.

Received 13 August 2019 | Accepted 7 December 2019 | Published 19 February 2020

\section{Introduction}

The cycling of molybdenum (Mo) in Earth's surface environments holds key information on the weathering and redox reactions that control atmospheric gas concentrations (Arnold et al., 2004; Dickson, 2017). This is because Mo isotopes (reported here as $\delta^{98 / 95} \mathrm{Mo}=\left[\left(\left({ }^{88} \mathrm{Mo} /{ }^{95} \mathrm{Mo}\right){ }_{\text {sample }} /\left({ }^{98} \mathrm{Mo} /{ }^{95} \mathrm{Mo}\right)\right.\right.$ NIST-SRM-3134) - 1 ] × 1000 [\%o]) can be fractionated during Mo removal from seawater, depending on the redox conditions of the sediment pore waters and overlying water column, and dissolved Mo speciation (Kerl et al., 2017). Reconstructing the $\delta^{98 / 95} \mathrm{Mo}$ values of seawater is a recognised method for assessing the extent of past euxinic conditions and is linked to ocean oxygenation (Pearce et al., 2008). Rivers are the largest input flux of Mo to oceans $\left(\sim 3.1 \times 10^{8} \mathrm{~mol} \mathrm{yr}^{-1}\right)$. Consequently, the isotope ratios of dissolved Mo in rivers $\left(\delta^{98 / 95} \mathrm{Mo}_{\text {diss }}\right)$ control the $\delta^{98 / 95}$ Mo values of seawater and estimations of the extent of past seawater euxinia from geochemical records (Archer and Vance, 2008).

The measured range of $\delta^{98 / 95} \mathrm{Mo}_{\text {diss }}$ values in rivers is $>2$ $\%$ o (Fig. 1). Some of this variability has been linked to the Mo isotope fractionation occurring during chemical weathering and the formation of secondary minerals, such as iron (Fe) and manganese (Mn) (oxyhydr)oxides (Pearce et al., 2010; Wang et al., 2015, 2018). However, other studies have emphasised the role of lithology and weathering of labile phases, such as sulfide minerals, in setting the $\delta^{98 / 95} \mathrm{Mo}_{\text {diss }}$ of rivers (Voegelin et al., 2012; Neely et al., 2018). It is important to constrain their relative importance to understand how and why $\delta^{98 / 95} \mathrm{Mo}_{\text {diss }}$ values of rivers might change. For instance, changes in the extent of primary and secondary weathering could lead to changes in the $\delta^{98 / 95} \mathrm{Mo}_{\text {diss }}$ of rivers over geological timescales, which may leave an imprint on seawater chemistry (Dickson, 2017). Untangling the dual controls of source and process on river $\delta^{98 / 95} \mathrm{Mo}_{\text {diss }}$ values is challenging (King and Pett-Ridge, 2018). This is primarily because we lack information on the $\delta^{98 / 95} \mathrm{Mo}$ values of rocks and soils in many river catchments (Archer and Vance, 2008)

Here, we measure $\delta^{98 / 95} \mathrm{Mo}_{\text {diss }}$ in river water alongside solid products of erosion and weathering found in river bed materials, suspended sediments and soils (Tables S-1-S-4). We focus on three sets of rivers that have contrasting bedrock geology (albeit with heterogeneities in each location): 13 rivers from the Southern Alps, New Zealand (metasedimentary);

\footnotetext{
1. Department of Earth Sciences, Durham University, South Road, Durham, DH1 3LE, UK

2. Department of Geography, Durham University, South Road, Durham, DH1 3LE, UK

3. School of Earth, Atmosphere and Environment, Monash University, Clayton, Victoria, 3800, Australia

4. State Key Laboratory of Geological Processes and Mineral Resources, School of Earth Resources, China University of Geosciences, Wuhan, 430074, Hubei, China

5. Department of Earth Sciences, University of Cambridge, Downing Street, Cambridge, CB2 3EQ, UK

Corresponding author (email: khoran@rvc.ac.uk)
} 


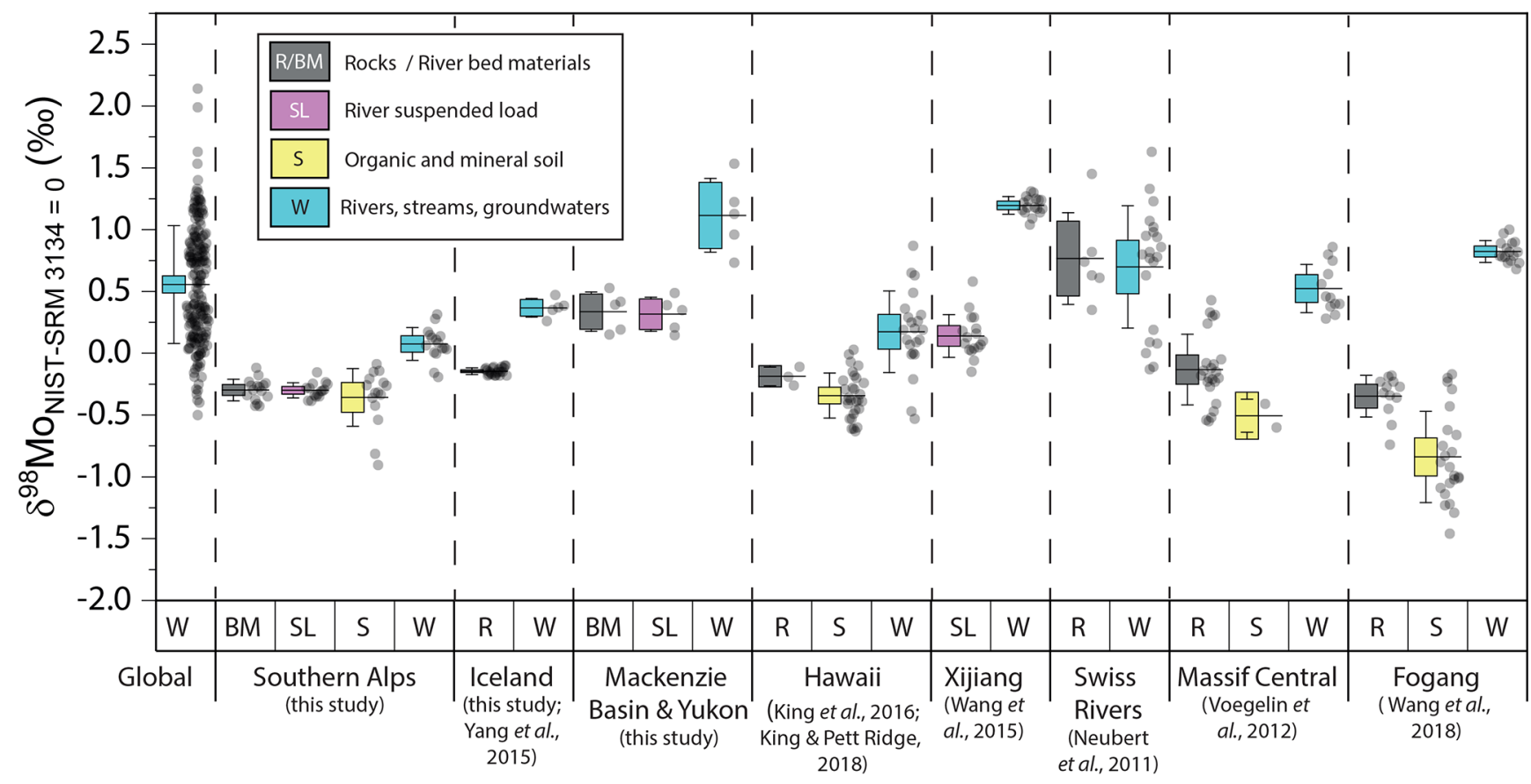

Figure 1 Molybdenum isotope ratios $\left(\delta^{98 / 95}\right.$ Mo, NIST-SRM3134 $=0 \%$ ) for this study (Southern Alps, Iceland, Mackenzie Basin and Yukon), alongside published measurements with: $\mathrm{R}=$ rocks, $\mathrm{BM}=$ river bed materials (grey); $\mathrm{SL}=\mathrm{suspended}$ load (pink); $\mathrm{S}=\mathrm{soils}$ (yellow); $\mathrm{W}=$ water (blue). Measurements are shown as grey dots, bars show the \pm 2 s.e. and whiskers \pm 2 s.d.

the Skaftá River, Iceland (volcanic); and the Mackenzie River and Yukon Rivers, Canada (sedimentary dominated) (Supplementary Information). We use the trace element rhenium (Re), which is hosted in similar phases as Mo but is not susceptible to uptake during Fe-Mn-(oxyhydr)oxide formation (Miller et al., 2011), to help track the imprint of Mo isotope fractionation during chemical weathering.

\section{Lithological Imprint on River Water $\delta^{98 / 95} \mathrm{Mo}$}

Chemical weathering can oxidise Mo in rocks to the soluble $\mathrm{MoO}_{4}{ }^{2-}$ anion, which can be leached from soils and delivered as dissolved Mo to rivers (Miller et al., 2011). The starting isotope ratios of Mo-bearing phases can vary, with contrasts between igneous and sedimentary rocks, where the $\delta^{98 / 95} \mathrm{Mo}$ values of the latter depend on the redox state of the depositional environment, and can vary by $\sim 2 \%$ at the outcrop scale (Pearce et al., 2010; Yang et al., 2015; Kendall et al., 2017; Neely et al., 2018; Li et al., 2019).

To constrain the composition of the rocks undergoing weathering, the most unweathered parts of river sediment loads can be used; these are typically found in the sand and silts of river bed materials in erosive settings (e.g., Hilton et al., 2010). In the western Southern Alps, bulk river bed material samples across 11 catchments have relatively homogenous isotope ratios, with a mean $\delta^{98 / 95} \mathrm{Mo}$ value (NIST-3134 $=0$ $\%$; Supplementary Information) of $-0.30 \pm 0.05 \%$ o $(n=11$, mean \pm 2 s.e. unless otherwise stated). These contrast with published rocks from Iceland $(-0.15 \pm 0.01 \%$; Yang et al., 2015) and our river bed materials from the Mackenzie Basin (0.38 \pm $0.14 \%$, n = 4) (Table S-1). The differences are consistent with the relatively organic carbon and sulfide poor greywacke of the Southern Alps (Roser and Cooper, 1990), which may represent oxic depositional conditions favouring lower $\delta^{98 / 95} \mathrm{Mo}$ values. In the Mackenzie Basin, black shales deposited under euxinic conditions may have higher $\delta^{98 / 95} \mathrm{Mo}$ (Johnston et al., 2012). When we compare $\delta^{98 / 95} \mathrm{Mo}_{\text {diss }}$ values of rivers at our study sites alongside published measurements, we find that river water $\delta^{98 / 95} \mathrm{Mo}_{\text {diss }}$ values are $\sim 0.2 \%$ o to $>1 \%$ o higher than their complementary solids (Fig. 1). General shifts in $\delta^{98 / 95} \mathrm{Mo}_{\text {diss }}$ values between locations can be explained by shifting rock compositions, but the systematically higher $\delta^{98 / 95} \mathrm{Mo}_{\text {diss }}$ values in streams and rivers requires further explanation.

Previous work has suggested that incongruent weathering of phases, such as sulfide and sulfate minerals, may play a role in setting the $\delta^{98 / 95} \mathrm{Mo}_{\text {diss }}$ values of rivers (Neubert et al., 2011; Voegelin et al., 2012) and groundwaters (Neely et al., 2018). To explore this, we examine $\delta^{98 / 95} \mathrm{Mo}$ values alongside concentration ratios of $[\mathrm{Mo}]$ to rhenium, [Re], in rivers, soils and sediments from the Southern Alps (Fig. 2). Rhenium is a mobile and soluble element that is also sourced from organic and sulfide phases, yet in contrast to Mo, Re is not thought to be incorporated into secondary weathering products (Miller et al., 2011). If preferential weathering of sulfide phases is responsible for the fractionation patterns, we would expect waters to have sulfide-like compositions (high $\delta^{98 / 95} \mathrm{Mo}$, high [Mo]/[Re]) (Miller et al., 2011; Neely et al., 2018), while the residue in soils would have lower $\delta^{98 / 95} \mathrm{Mo}$ and $[\mathrm{Mo}] /[\mathrm{Re}]$ values than parent materials. Our data lie perpendicular to this (Fig. 2), with soils having Mo enrichment relative to Re when compared to river bed materials. A negative pattern between $\delta^{98 / 95} \mathrm{Mo}$ and $[\mathrm{Mo}] /[\mathrm{Re}]$ across our sample set is consistent with a process that preferentially removes light Mo isotopes from waters, and leaves a complementary pool of light Mo isotopes in soils.

\section{Chemical Weathering Imprint on River Water $\delta^{98 / 95} \mathrm{Mo}$}

Field observations and experiments suggest Mo can be removed from solution during Fe-Mn (oxyhydr) oxide formation (Barling and Anbar, 2004; Goldberg et al., 2009; Pearce et al., 2010) and can be adsorbed onto organic matter (Siebert et al., 2015; King et al., 2018). To explore the potential imprint of this process in both the western Southern Alps and our wider sample set, 


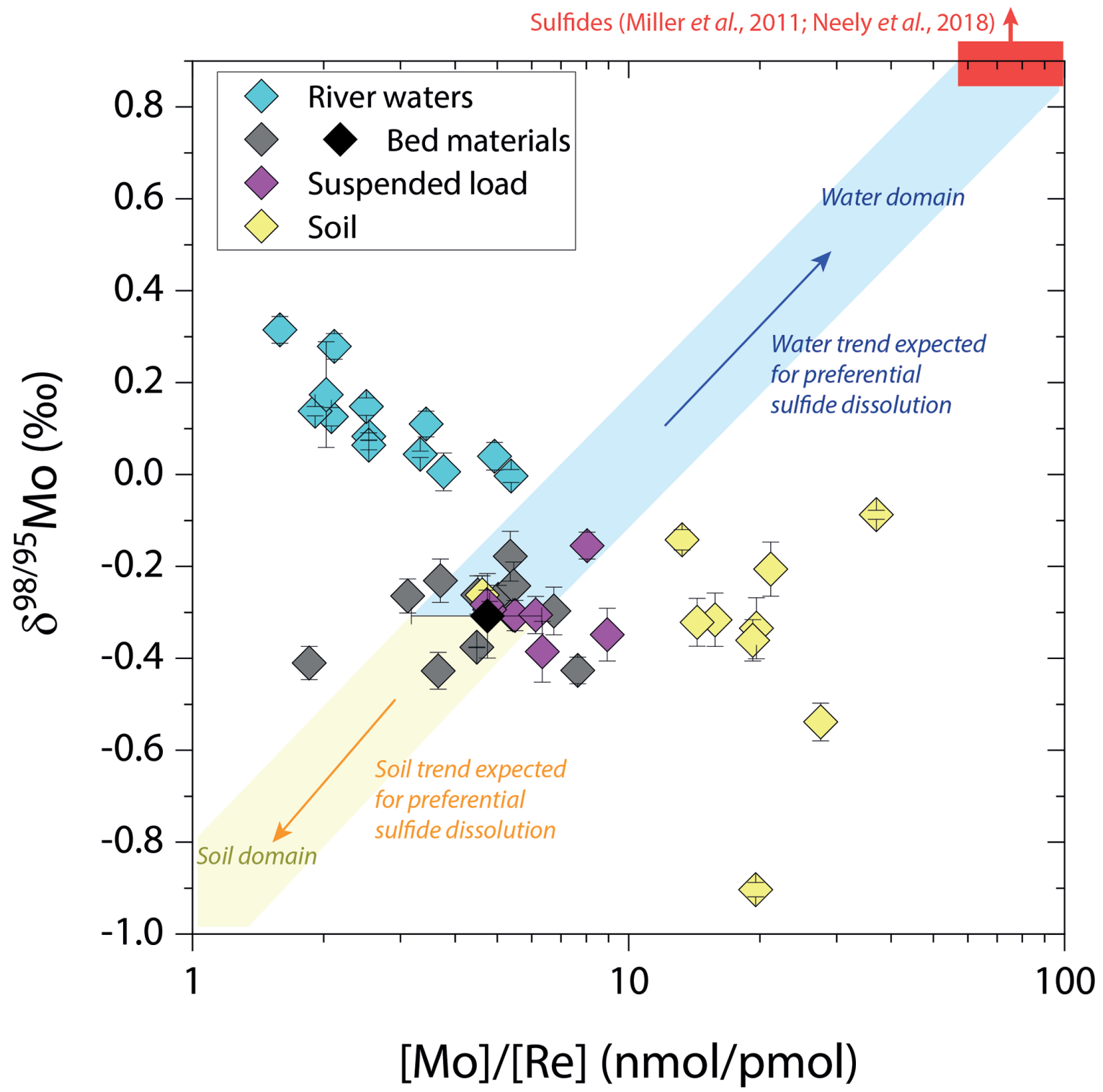

Figure 2 The Mo isotope ratios of materials from the western Southern Alps, New Zealand, versus the Mo to Re concentration ratios for river waters (light blue), river bed materials (grey), suspended load (purple) and soils (yellow). Black diamond is the mean of the bed material samples. Shaded domains show the expected fields of soil and water compositions if preferential dissolution of sulfides was occuring, but data lie perpendicular to this trend implying an alternative mechanism is responsible for fractionation patterns observed.

we use [Mo]:[Re] ratios to quantify Mo removal from solution (Supplementary Information). Following an approach taken for several other isotope systems (Millot et al., 2010; Dellinger et al., 2015), the fraction of Mo left in solution after secondary mineral formation $\left(f \mathrm{Mo}_{\text {diss }}\right)$ is:

$$
f \mathrm{Mo}_{\text {diss }}=\frac{([\mathrm{Mo}] /[\mathrm{Re}])_{\mathrm{diss}}}{([\mathrm{Mo}] /[\mathrm{Re}])_{\mathrm{rock}}}
$$

where $([\mathrm{Mo}] /[\mathrm{Re}])_{\text {diss }}$ is the ratio of Mo to Re in the dissolved products of weathering (river water), and $([\mathrm{Mo}] /[\mathrm{Re}])_{\text {rock }}$ is the ratio of the elements in the unweathered parent. A value of $f \mathrm{Mo}_{\text {diss }}=1$ suggests $\mathrm{Mo}$ is released congruently to the dissolved phase alongside Re. A value of $f \mathrm{Mo}_{\text {diss }}<1$ suggests less Mo loss relative to Re from the dissolved phase (i.e. Mo retention in secondary minerals).

To account for lithological controls on $\delta^{98 / 95} \mathrm{Mo}_{\text {diss }}$ between basins (Fig. 1), we calculate the difference between river water and source rock: $\Delta^{98 / 95} \mathrm{Mo}_{\text {diss-BM }}=\delta^{98 / 95} \mathrm{Mo}_{\text {diss }}$ $\delta^{98 / 95} \mathrm{Mo}_{\text {вм }}$ (Table S-3). Despite the diversity of our studied catchments in terms of geology, climate and scale, the $\Delta^{98 / 95} \mathrm{Mo}_{\text {diss-BM }}$ values are correlated with $f \mathrm{Mo}_{\text {diss }}$ (Fig. 3): as the fraction of Mo left in solution decreases, $\Delta^{98 / 95} \mathrm{Mo}_{\text {diss-BM }}$ values increase. Notwithstanding the uncertainties on $f \mathrm{Mo}_{\text {diss }}$ (Supplementary Information), the data suggest a common process across all of our study sites that modifies $\delta^{98 / 95} \mathrm{Mo}_{\text {diss }}$ values from those of the parent materials and decreases $\mathrm{Mo} /$ Re ratios as $\delta^{98 / 95} \mathrm{Mo}_{\text {diss }}$ values increase (Fig. 2). Adsorption of Mo to Fe and Mn (oxyhydr)oxides and/or organic matter removes Mo from solution (Goldberg et al., 1996) and preferentially scavenges light isotopes (Barling and Anbar, 2004; Goldberg et al., 2009; King et al., 2018). We find that experimentally derived fractionation factors for Mo uptake by Fe and Mn (oxyhydr)oxides are consistent with our new data (Fig. 3), supporting inferences from a granitic weathering profile (Wang et al., 2018).

Biological processes could influence $\delta^{98 / 95} \mathrm{Mo}_{\text {diss }}$ values if plants fractionate Mo during uptake (Malinovsky and Kashulin, 2018) and previous observations on organic rich 


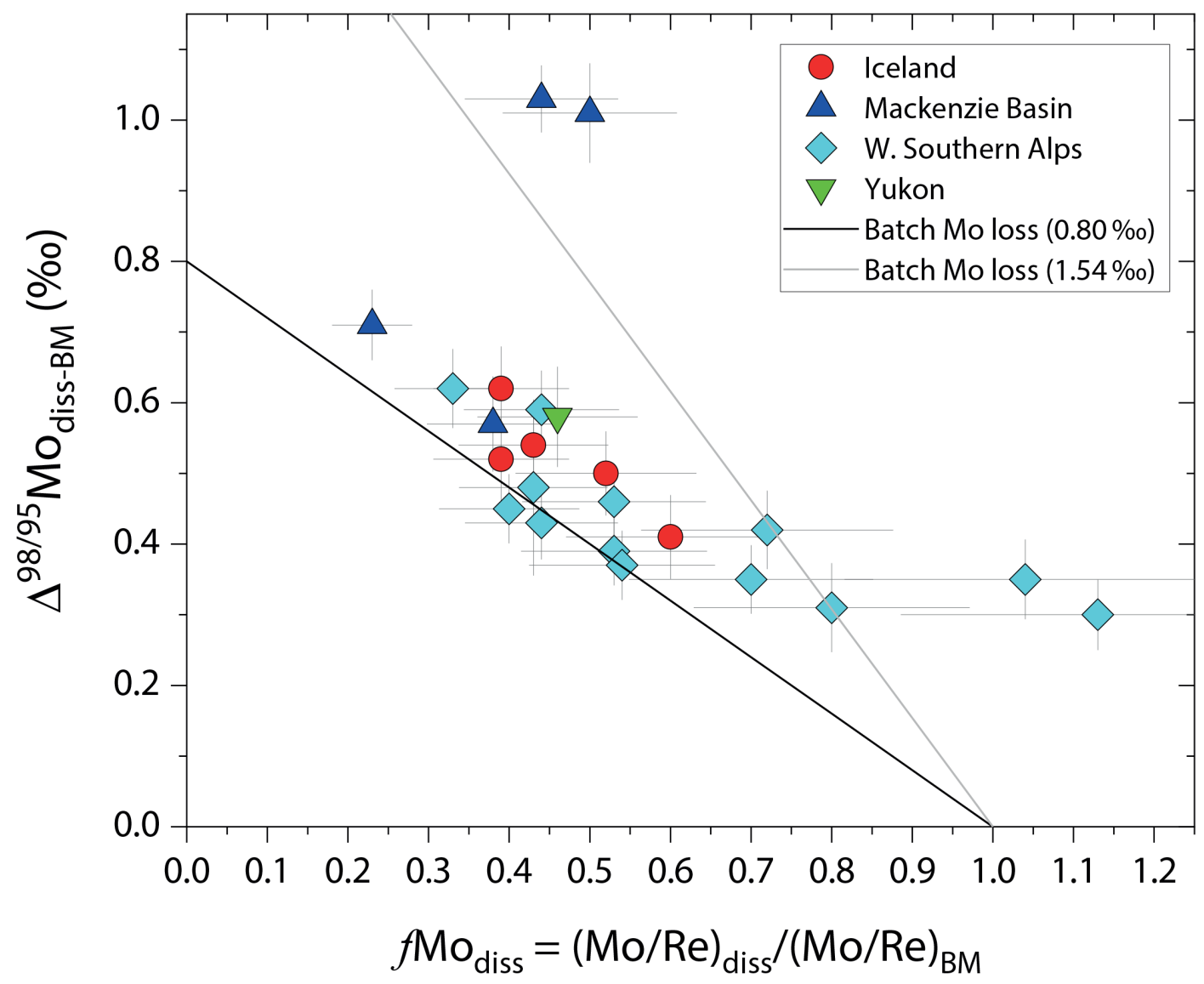

Figure 3 The fraction of Mo remaining in river water, $f \mathrm{Mo}_{\text {diss, }}$ estimated using the ratio of Mo to rhenium (Re) in the dissolved load relative to parent materials, versus the difference in $\delta^{98 / 95} \mathrm{Mo}$ between river water and river bed materials. Lines are a batch fractionation model using fractionation factors between a solution and secondary mineral phases, based on fractionation factors of $-0.8 \%$ (black) to $-1.4 \%$ (grey) (Goldberg et al., 2009; Barling and Anbar, 2004). Error bars indicated for $f$ Modiss are the propagated 2 s.e. errors on $(\mathrm{Mo} / \mathrm{Re})_{\mathrm{BM}}$, which is the main source of uncertainty. Error bars for $\Delta^{98 / 95} \mathrm{Mo}_{\text {diss-BM }}$ incorporate the $2 \mathrm{~s} . \mathrm{d}$ analytical error on $\delta^{98 / 95} \mathrm{Mo}_{\text {diss }}$ and the 2 s.e. of the mean $\delta^{98 / 95} \mathrm{Mo}_{\text {BM. }}$.

soils document a net enrichment in heavier isotopes compared to the original bedrock (Siebert et al., 2015). However, the organic rich soil layers from the western Southern Alps have similar $\delta^{98 / 95}$ Mo values to river bed materials (Figs. 2 and S-5). Surface soil litters with organic carbon contents $>4 \mathrm{wt}$. \% have a mean $\delta^{98 / 95} \mathrm{Mo}=-0.23 \pm 0.11 \%$ o $(\mathrm{n}=5)$, which is the same within uncertainty as the river bed material at this location $\left(\delta^{98 / 95} \mathrm{Mo}=-0.26 \pm 0.04 \%\right.$; Table S-4).

In contrast, the weathered colluvium sediments with low organic matter contents $(<1.5 \%)$ have a mean $\delta^{98 / 95} \mathrm{Mo}=$ $-0.52 \pm 0.28 \%$ o $(n=4)$, with $\delta^{98 / 95} \mathrm{Mo}$ values reaching $-0.90 \pm$ $0.07 \%$ o (Figs. 2 and S-5). Weathered materials in the surface environment thus offer a complementary reservoir of Mo to river water (Figs. 1 and 2). These data are comparable to those of Siebert et al. (2015), who found lower $\delta^{98 / 95} \mathrm{Mo}$ in the deeper portions of soil horizons from Hawaii, Iceland and Puerto Rico. A light Mo reservoir in mineral soils is consistent with $\delta^{98 / 95}$ Mo measurements on soil and root samples from the Massif Central (Voegelin et al., 2012, Fig. 1) and soil samples paired to local bedrock samples in Hawaii (King et al., 2016).

In the Mackenzie Basin, we find the highest average $\Delta^{98 / 95} \mathrm{Modiss-BM}_{\text {value }}(0.78 \pm 0.23 \%$ o) (Fig. 3$)$. This would suggest a weathering regime that promotes Mo removal from solution, potentially by $\mathrm{Fe}-\mathrm{Mn}$ (oxyhydr)oxide formation. In contrast, the Southern Alps have a lower mean value of $\Delta^{98 / 95} \mathrm{Mo}_{\text {diss-BM }}(0.42 \pm 0.09 \%$ o). The higher erosion rates in this setting drive high oxidative weathering fluxes (Horan et al., 2017) but a lower extent of primary and secondary weathering compared to the Mackenzie Basin (Supplementary
Information). We acknowledge that the dataset of Mo isotope ratios is limited in size compared to other isotope systems (Dellinger et al., 2015) and for the published datasets (Fig. 1) $f \mathrm{Mo}_{\text {diss }}$ cannot be estimated without complementary $\operatorname{Re}$ analyses. In addition, understanding temporal and spatial changes in water flow paths and Mo flux at the catchment scale requires flux weighted $\delta^{98 / 95}$ Mo values (King and Pett-Ridge, 2018). Nevertheless, the contrast between our study locations suggests that primary weathering coupled to the formation of specific mineral phases (which are likely to be linked to bioclimatic regimes, erosion rates, lithology) could play a role in setting differences in $\Delta^{98 / 95} \mathrm{Mo}_{\text {diss-BM. }}$.

\section{Wider Implications}

Our approach attempts to tease apart the source (lithology) versus process (secondary mineral formation) controls on $\delta^{98 / 95} \mathrm{Mo}_{\text {diss }}$ in rivers. Although lithological differences account for $\sim 1 \%$ variability (Fig. 1), we find that the partitioning of Mo between the dissolved load and solid weathering products $\left(\mathrm{MMo}_{\text {diss }}\right)$ can produce an additional $\sim 1 \%$ offset (Fig. 3). These findings indicate that changes in primary and secondary weathering patterns could give rise to changes in $\delta^{98 / 95} \mathrm{Mo}_{\text {diss }}$ values. Over geological time, this could influence the Mo isotope ratios of lakes, coastal regions and the $\delta^{98 / 95} \mathrm{Mo}$ values of seawater. Shifts of as little as $\sim 0.3 \%$ in continental runoff impact how $\delta^{98 / 95} \mathrm{Mo}$ values of sedimentary rocks are used to reconstruct palaeoredox conditions (Dickson, 2017). Global changes in chemical weathering on land are reflected 
in seawater lithium isotope records over the Cenozoic (e.g., Misra and Froelich, 2012; Dellinger et al., 2015). Our data raise the intriguing possibility that secular trends in $\delta^{98 / 95} \mathrm{Mo}_{\text {diss }}$ could also result from changes in the extent of primary and secondary weathering (Fig. 3), and call for future work to better constrain $\delta^{98 / 95} \mathrm{Mo}$ fractionation in large rivers catchments to understand spatio-temporal variability.

\section{Acknowledgements}

KH was funded by a Natural Environment Research Council (NERC, UK) PhD award. RGH was supported by a European Research Council Starting Grant (ERC-StG, 678779, ROC- $-\mathrm{CO}_{2}$ ). Fieldwork in New Zealand was funded by a Durham University Grant (Building Research Links in New Zealand) to RGH. Fieldwork support for Canada came from the British Society for Geomorphology (RGH) and the Carnegie Trusts (ETT). Research in the Mackenzie Basin was carried out under Scientific Research License No. 14802 issued by the Aurora Research Institute and in the Yukon River under License No. 13-47S\&E. We are thankful to Mathieu Dellinger for discussions and Christopher Pearce, Rebecca Neely, Geoff Nowell, Chris Ottley and Amanda Hayton for additional laboratory support.

\section{Editor: Sophie Opfergelt}

\section{Author Contributions}

$\mathrm{KH}, \mathrm{RGH}$ and $\mathrm{KB}$ conceived the research and designed the study. $\mathrm{KH}, \mathrm{RGH}, \mathrm{ETT}, \mathrm{SH}$ and $\mathrm{KB}$ collected the samples. $\mathrm{KH}$ undertook the geochemical analyses under the supervision of AMW. KH interpreted the data with RGH and in discussion with AMW, KB, DS and ETT. KH and RGH wrote the manuscript with input from co-authors.

\section{Additional Information}

Supplementary Information accompanies this letter at http:// www.geochemicalperspectivesletters.org/article2005.

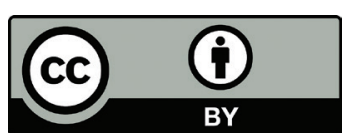

This work is distributed under the Creative Commons Attribution 4.0 License, which permits unrestricted use, distribution, and reproduction in any medium, provided the original author and source are credited. Additional information is available at http://www.geochemicalperspectivesletters.org/copyrightand-permissions.

Cite this letter as: Horan, K., Hilton, R.G., McCoy-West, A.J., Selby, D., Tipper, E.T., Hawley, S., Burton, K.W. (2020) Unravelling the controls on the molybdenum isotope ratios of river waters. Geochem. Persp. Let. 13, 1-6.

\section{References}

ARCHER, C., VANCE, D. (2008) The isotopic signature of the global riverine molybdenum flux and anoxia in the ancient oceans. Nature Geoscience 1, 597-600.

ArNold, G.L., ANBAr, A.D., BArling, J., LyOns, T.W. (2004) Molybdenum isotope evidence for widespread anoxia in mid-proterozoic oceans. Science 304, 87-90.

BARLING, J., ANBAR, A.D. (2004) Molybdenum isotope fractionation during adsorption by manganese oxides. Earth and Planetary Science Letters 217, 315-329.
Dellinger, M., Gaillardet, J., Bouchez, J., Calmels, D., Louvat, P., Dosseto, A., Gorge, C., Alanoca, L., Maurice, L. (2015) Riverine $\mathrm{Li}$ isotope fractionation in the Amazon River basin controlled by the weathering regimes. Geochimica et Cosmochimica Acta 164, 71-93.

DiCKSON, A.J. (2017) A molybdenum-isotope perspective on Phanerozoic deoxygenation events. Nature Geoscience 10, 721-726.

GoldberG, S., Forster, H.S., Godfrey, C.L. (1996) Molybdenum Adsorption on Oxides, Clay Minerals, and Soils. Soil Science Society of America Journal 60, 425-432.

Goldberg, T., Archer, C., VAnce, D., Poulton, S.W. (2009) Mo isotope fractionation during adsorption to Fe (oxyhydr) oxides. Geochimica et Cosmochimica Acta 73, 6502-6516.

Hilton, R.G., Galy, A., Hovius, N., Horng, M.J. And Chen, H. (2010) The isotopic composition of particulate organic carbon in mountain rivers of Taiwan. Geochimica et Cosmochimica Acta 74, 3164-3181.

Horan, K., Hilton, R.G., Selby, D., Ottley, C.J., Gröcke, D.R., Hicks, M., BurTon, K.W. (2017) Mountain glaciation drives rapid oxidation of rock-bound organic carbon. Science Advances 3, e1701107.

Johnston, D.T., Macdonald, F.A., Gill, B.C., Hoffman, P.F., SchraG, D.P. (2012) Uncovering the Neoproterozoic carbon cycle. Nature 483, 320.

Kendall, B., DaHL, T.W. Anbar, A.D. (2017) The stable isotope geochemistry of molybdenum. Reviews in Mineralogy and Geochemistry 82, 683-732.

Kerl, C.F., Lohmayer, R., Bura-Nakic , E., Vance, D., Planer-FriedRICH, B. (2017) Experimental confirmation of isotope fractionation in thiomolybdates using ion chromatographic separation and detection by multicollector ICPMS. Analytical Chemistry 89, 3123-3129.

King, E.K., PetT-RidGE, J.C. (2018) Reassessing the dissolved molybdenum isotopic composition of ocean inputs: The effect of chemical weathering and groundwater. Geology 46, 955-958.

King, E.K., Thompson, A., Chadwick, O.A., Pett-Ridge, J.C. (2016) Molybdenum sources and isotopic composition during early stages of pedogenesis along a basaltic climate transect. Chemical Geology 445, 54-67.

KInG, E.K., Perakis, S.S., PetT-RIdge, J.C. (2018) Molybdenum isotope fractionation during adsorption to organic matter. Geochimica et Cosmochimica Acta 222, 584-598.

MalinOvsKy, D., KasHulin, N.A. (2018) Molybdenum isotope fractionation in plants measured by MC-ICPMS. Analytical Methods 10, 131-137.

Miller, C.A., Peucker-Ehrenbrink, B., Walker, B.D., MarcanTONIO, F. (2011) Re-assessing the surface cycling of molybdenum and rhenium. Geochimica et Cosmochimica Acta 75, 7146-7179.

Millot, R., Vigier, N., Gaillardet, J. (2010) Behaviour of lithium and its isotopes during weathering in the Mackenzie Basin, Canada. Geochimica et Cosmochimica Acta 74, 3897-3912.

Misra, S., Froelich, P.N. (2012) Lithium Isotope History of Cenozoic Seawater: Changes in Silicate Weathering and Reverse Weathering. Science 335, 818-823.

Li, Y., McCoy-West, A.J., Zhang, S., Selby, D., Burton, K.W., Horan, K. (2019) Controlling mechanisms for molybdenum isotope fractionation in porphyry deposits: the Qulong example. Economic Geology 114, 981-992.

Neely, R.A., Gislason, S.R., Ólafsson, M., McCoy-West, A.J., Pearce, C.R., BurTon, K.W. (2018) Molybdenum isotope behaviour in groundwaters and terrestrial hydrothermal systems, Iceland. Earth and Planetary Science Letters 486, 108-118.

Neubert, N., Heri, A.R., Voegelin, A.R., Nägler, T.F., Schlunegger, F., VILLA, I.M. (2011) The molybdenum isotopic composition in river water: constraints from small catchments. Earth and Planetary Science Letters 304, 180-190.

Pearce, C.R., Cohen, A.S., Coe, A.L., Burton, K.W. (2008) Molybdenum isotope evidence for global ocean anoxia coupled with perturbations to the carbon cycle during the Early Jurassic. Geology 36, 231-234.

Pearce, C.R., Burton, K.W., von Strandmann, P.A.P., James, R.H., GísLASON, S.R. (2010) Molybdenum isotope behaviour accompanying weathering and riverine transport in a basaltic terrain. Earth and Planetary Science Letters 295, 104-114.

Roser, B.P., COOPER, A.F. (1990) Geochemistry and terrane affiliation of Haast Schist from the western Southern Alps, New Zealand. New Zealand Journal of Geology and Geophysics 33, 1-10.

Siebert, C., Pett-Ridge, J.C., Opfergelt, S., Guicharnaud, R.A., Halliday, A.N., BurTon, K.W. (2015) Molybdenum isotope fractionation in soils: Influence of redox conditions, organic matter, and atmospheric inputs. Geochimica et Cosmochimica Acta 162, 1-24. 
Voegelin, A.R., NÄgler, T.F., PettKe, T., Neubert, N., Steinmann, M., Pourret, O., VillA, I.M. (2012) The impact of igneous bedrock weathering on the Mo isotopic composition of stream waters: Natural samples and laboratory experiments. Geochimica et Cosmochimica Acta 86, 150-165.

Wang, Z., MA, J., Li, J., Wei, G., Chen, X., Deng, W., Xie, L., Lu, W., ZoU, L. (2015) Chemical weathering controls on variations in the molybdenum isotopic composition of river water: Evidence from large rivers in China. Chemical Geology 410, 201-212.

WAnG, Z., MA, J., Li, J., WeI, G., ZenG, T., Li, L., ZhANG, L., Deng, W. XIE, L., LIU, Z. (2018) Fe (hydro) oxide controls Mo isotope fractionation during the weathering of granite. Geochimica et Cosmochimica Acta 226, 1-17.

Yang, J., Siebert, C., Barling, J., Savage, P., Liang, Y.H., HallidaY, A.N. (2015) Absence of molybdenum isotope fractionation during magmatic differentiation at Hekla volcano, Iceland. Geochimica et Cosmochimica Acta 162, 126-136. 